University of San Diego

Digital USD

Undergraduate Honors Theses

Theses and Dissertations

Winter 12-18-2017

\title{
Manipulated Manipulation: The Political Origins and Implications of Shakespeare's Henry V
}

Kate Morton

University of San Diego

Follow this and additional works at: https://digital.sandiego.edu/honors_theses

Part of the Dramatic Literature, Criticism and Theory Commons

\section{Digital USD Citation}

Morton, Kate, "Manipulated Manipulation: The Political Origins and Implications of Shakespeare's Henry V" (2017). Undergraduate Honors Theses. 48.

https://digital.sandiego.edu/honors_theses/48

This Undergraduate Honors Thesis is brought to you for free and open access by the Theses and Dissertations at Digital USD. It has been accepted for inclusion in Undergraduate Honors Theses by an authorized administrator of Digital USD. For more information, please contact digital@sandiego.edu. 
Shakespeare's Henry $V$ has long been one of the most ambiguous adaptations of the story of England's most celebrated historical figure: King Henry V. This adaptation raises the question of why Shakespeare presents Henry V in a way that not only differs significantly from the other accounts of Henry V's life, but is also entirely ambiguous as to whether this presentation of Henry V's character is optimistic or pessimistic in nature.

Henry V is Shakespeare's most developed character because he plays a significant role in three of Shakespeare's history plays. He is the character that Shakespeare spent the most time creating, yet when he becomes king his traits and motivations become something entirely ambiguous. This, as I will argue, is due to Shakespeare's own fears about the prospect of a Scottish succession to the English throne and how those fears are utilized in making larger claims about his political system as a whole. Shakespeare was heavily manipulated not only by the political climate, culture, ideals, and restrictions of his time, but he also sought to manipulate those aspects of his society through his play, Henry $V$. His writing relies on these cultural facts and ideas in order to conceal his more subversive and politically dangerous messages. He is manipulated by a fear of censorship, the English cultural narrative, and his own feelings toward succession in his attempt to manipulate his audience. In short, "the manipulated and manipulating complexity of Henry's self-presentation" leads to a heightened sense of ambiguity throughout the piece (Patterson 139). This ambiguity is then a manifestation of Shakespeare's own manipulated and manipulating self-presentation as he deals with the stresses of a possible political succession 
In my thesis, I will argue that the ambiguities present in Henry $V$ are actually a result of Shakespeare's own stress over the political succession looming over England at the time of the play's creation, and how those fears, questions, and concerns over leadership seep into his work. Throughout Henry $V$, Shakespeare intentionally uses this ambiguity to accomplish three objectives. The first is to subvert the major tenets of his culture by creating an ambiguity that contrasts and undermines the Elizabethan worldview. The second is to protect himself from censorship and persecution by hiding behind the duplicitous nature of ambiguity. The third and final goal Shakespeare seeks to accomplish is to express his own stresses and fears about succession by using ambiguity to question the concept of kingship as a whole.

Before we delve into the discussion of ambiguity present in this piece, let's first clarify who Henry V was historically. From medieval accounts of Henry V, such as Raphael Holinshed, as well as more modern accounts, such as Gwilym Dodd's article in History Today, we can start to piece together the historically factual aspects of Henry's character and actions. The first notable trait of Henry V is that he "showed himself a valiant knight" (Holinshed 84). It is relevant that Henry be a good warrior because it was what was expected of good leaders at the time. It also shows that he had a deeper understanding of the war that he was forcing his citizens to be a part of. He understood what battle was like, and, more than that, he was good at it. $\mathrm{He}$ was also "a dynamic, capable and experienced tactician" (Dodd 3). This is another important element of Henry's success as a leader because it meant he was able to effectively use tactics to beat a much larger army at Agincourt. This would lead to him winning a miraculous victory, which would in turn spark the mystification and celebration of him as one of England's most important historical figures. This understanding of Henry's skill as a tactician will be 
complicated when we examine the French accounts of the Battle of Agincourt. Henry V was also a leader who "remember[ed] from whom all victories are sent" (Holinshed 85). Henry was a very pious man who historically attributed his victories not to his skill as a leader, warrior, and tactician, but to God. This is something that Shakespeare will mutate and undermine significantly in his text in order to bring a larger question of what kingship is into the forefront of his piece. It is also important to realize that Henry $\mathrm{V}$ was a "young man intent on action and adventure" when he became king; therefore, it is extremely likely that in addition to being a valiant warrior, a skilled tactician, and a pious man he was also "strong-willed, impetuous" and extremely lucky in his victory at Agincourt (Dodd 10). Dodd's analysis of Henry as such shows us that, for all of the glorification he receives as one of England's most successful kings, he was not a genius or a god but a man who got very lucky. Henry V was also the son of a usurper and therefore had no true hereditary claim to the crown of England nor the crown of France. Yet for all of these contradictions to the glorified image of him, Henry V is remembered first and foremost as a just king. According to Holinshed, as he and his soldiers marched through the French countryside, Henry ordered his men not "to hurt or doo anie violence either to priests, women, or anie such as should be found without weapon or armor, and not readie to make resistance" (Holinshed 79). This protection of noncombatants is a major tenet in the just war tradition, and, by following it, Henry showed himself to be concerned with justice even in the midst of war. This is another element of Henry that Shakespeare will manipulate and question through his stage portrayal of the famous king.

Although Henry V is remembered as a just and wonderful leader who operated in accordance with the will of God, his historical actions tell a very different story. From a modern 
perspective, Henry V's actions during the battle of Agincourt can be classified as war crimes. His war crime was murdering French prisoners of war because he feared "his enimies should gather togither againe, and begin a new field" (Holinshed 83). Holinshed tries to excuse this behavior earlier in his chronicle by including the cultural narrative of the French murdering the unprotected boys at the English camp during the Battle of Agincourt. This story was created after the battle by the English to excuse Henry's unjust actions in killing prisoners of war. However, by including the actual reasoning for the massacre, Holinshed shows us that this was a cruel and callous tactic employed by Henry in order to try to win the battle. "When this lamentable slaughter was ended," the English did in fact win the battle but at the cost of justice and proper wartime procedures (Holinshed 83). Even Shakespeare's contemporaries seem to have misgivings about the murder of the French prisoners of war: Holinshed, who does nothing but glorify Henry throughout his chronicle of the king's achievements, refers to the slaughter as a lamentable act. The characterization of Henry $\mathrm{V}$ as a war criminal is very important in complicating the glorified image we have of Henry V today.

Regardless of his war crimes, Henry V was worshiped by the medieval English people. In describing Henry V at the end of his historical account, Holinshed characterizes Henry as a person "rightlie representing his heroicall affects...and of great grace and power to persuade" (Holinshed 89). This glorification of Henry by English historians is influential in Shakespeare's choice to make Henry $V$ the most ambiguous of his history plays. Shakespeare uses this king who was commended for his power to persuade in order to persuade his audience regarding political issues of his time while still protecting himself and hiding his true intentions behind the image of this glorified king. 
Today, however, we view Henry V very differently. This is because through further study of the leadership of both the French and English at the Battle of Agincourt, "there is room to question the quality of leadership that Henry displayed and the unblemished reputation which he has subsequently enjoyed" (Dodd 2). We now know that the English victory at the battle of Agincourt was more a result of French failings than English successes. For instance, "the French had it within their grasp to inflict a decisive defeat on the English;" however, due to "a number of ill-considered decisions, their overconfidence and bad luck combined to let victory slip through their fingers" at the battle of Agincourt (Dodd 6). The French mistakes and lack of sufficient leadership were just as important in determining the outcome of the battle as Henry's leadership was. The ineffective French king made Henry look brilliantly effective in comparison. In addition, the battle itself was not sought after by Henry but was instead forced upon him when the English army's "path was blocked at Agincourt" by the French army "and battle was forced upon" them (Dodd 7). This shows us that the most favorable aspect of the battle for the English army was a result of a French mistake in forcing the battle in a location that gave the English the advantage. The great tactician Henry did not use his skills in deciding the location of the battle; instead, it was the failure on the part of the French tacticians that gave the English the upper hand. Because of just "how unexpected the victory had been and how close the English had come to catastrophe" the English army began to view the victory at Agincourt as "a sign of God's approval" (Dodd 8). The victory at Agincourt was interpreted by the English as God approving of the usurper's son, Henry V. In reality, the victory was the result of a combination of lucky coincidences and obtuse French tacticians. Even with this divine approval after the battle of Agincourt, Henry still ran England without a divine right for the majority of his reign. 
Shakespeare will use this disparity between when Henry became king and when Henry got God's approval to question the medieval concepts of divine right and divine order in his play. This conception of divine approval is used by historians to justify Henry's tactical mistakes. Historically, Henry's tactical decision to march to Calais “could not be justified on its own terms, so writers resorted to the image of divinely inspired leadership to explain the king's actions" (Dodd 9). In actuality, "it was victory at Agincourt which retrospectively justified Henry's" choices and not his expert use of tactics or divine intervention (Dodd 9). Henry got lucky and because it turned out well he is viewed as one of the most successful English Kings. It could have very easily turned out poorly for the English, had France had better leadership. Had this been the case, Henry would be viewed as one of the worst leaders in English history. Unfortunately, in the long run, Henry’s actions led to “Agincourt [being] a hollow victory because it engendered unrealistic expectations" at the same time that "it blinded Henry and his advisers to the strategic impossibility that England could ever subdue its neighbour across the channel" (Dodd 15). This one victory at the Battle of Agincourt actually caused more harm than good. It led to more war that Henry himself was not involved in because of his untimely death. This instability and war led his line to lose the crown of France and reignited civil unrest in England. The usurpation of the French crown was unsuccessful and an overstretch on Henry's part. Yet Henry is still seen as a great king because he died before the consequences of his actions could come to fruition and instead left his son to deal with those consequences. Although "the victory at Agincourt gave Henry the initiative," it ended up causing "one of the most intensive periods of fighting seen in the [Hundred Year's War]" (Dodd 15). These are the real results of Henry's leadership in the Battle of Agincourt. 
Now that we have created a more realistic picture of the legendary King Henry V, we can examine about how Shakespeare dramatizes this English national figure in his play Henry $V$. From the traits and actions of this historical figure, Shakespeare will craft a story by manipulating history in order to make topical political claims about his own time. Shakespeare's Henry $\mathrm{V}$ is significantly different from the historical Henry V. These differences are very important because they allow Shakespeare to create and emphasize the ambiguities surrounding his characterization of Henry V. Throughout the play, Henry's actions complicate the traits that other historians of Shakespeare's time attributed to Henry. For example, in regards to Henry's piety, Shakespeare's Henry explicitly take bribes from the church. We see this in the second scene of the play when Canterbury promises that "the spirituality will raise [him] such a mighty sum as never did the clergy at one time bring into any of [his] ancestors" if Henry goes to war with France to take the French crown (Henry V 1.2.279-282). This complicates the idea that Henry is pious because, although he may be praising God, he is also not only allowing for blatant corruption to take place in the Church but is also participating in it himself for political and monetary gain. This piety is further complicated by the fact that Henry does not have a divine right to the throne because he is the son of a usurper. It could be argued that one of the reasons Henry goes to France, in Shakespeare's play, is to get money from the church. In this case Henry's motivations for war are extremely problematic and at odds with the picture we have of him from Holinshed as a pious ruler.

Shakespeare's Henry also delivers an incredibly vile speech at the gates of Harfleur. In this speech he threatens that if the governor does not surrender, then "the blind and bloody soldier with foul hand" will "defile the locks of [their] shrill-shrieking daughters," that their 
"fathers [will be] taken by the silver beards and their most reverend heads dash'd to the walls," and finally that "[their] naked infants [will be] spitted upon pikes" (Henry V 3.3.1292-1297). The language that Shakespeare uses in this speech is incredibly violent and, regardless of the intention behind the text, the audience will still hear their most glorified king say these words and make these threats. The entire speech goes against the idea of a just war; however, Shakespeare defends Henry's choice to kill the French prisoners of war during the Battle of Agincourt. This complicates the explanation of Henry as being the ideal Machiavellian leader, a concept that we will examine further later in this paper, because Shakespeare does not include both aspects of Henry's use of Machiavellian principles. In essence, he omits one of the most notable incidents that Henry callously uses cruelty as a tool as Machiavelli would have the ideal ruler do. In fact, in the incident with the murder of the French prisoners of war, Shakespeare justifies Henry's choice to "cut the throats of" the French prisoners of war he has by setting up Henry's reaction as a response to the death of the boys (Henry V 4.7.2588-2590). This makes Henry's execution of French prisoners of war an emotional reaction to the violation of the conduct of just war, as opposed to an actual violation of that conduct itself. Henry is not a war criminal here but instead is reacting to the death of the boys. In doing so, Henry becomes an emotional, unstable, and reactionary leader as opposed to one operating on disturbing, yet justifiable, Machiavellian principles. Shakespeare chooses selectively from his source material here in order to paint Henry in a slightly better light, and, in doing so, he makes him more ambiguous.

The final thing that Henry does, and arguably the most problematic, is question the divine order of the universe. We will discuss the details of this divine order later, but for now we should 
look at the ways in which Henry is undermining this order through his words and actions. The first instance of this questioning occurs when Henry asks "what art thou, thou idol ceremony" (Henry V 4.1.2090-2092). Ceremony is a manifestation of the divine order that is the structure of the Elizabethan worldview. Through questioning ceremony and Henry's role as King by being usurper's son without a clear Divine Right to rule, Shakespeare is also questioning God and the structure of the universe. He sets ceremony and divine order up as a false idol blocking man from seeing the actual nature of the world. Henry goes on to accuse ceremony of being a "proud dream that play'st so subtly with a king's repose" (Henry V 4.1.2107-2108). Here he's calling ceremony and the order of the world a dream. He is explicitly saying the the order of the universe, the fundamental of medieval culture, is a lie. He finishes his critique of ceremony by arguing that without this false order and this lie of ceremony any common man has "the forehand and vantage of a king" (Henry V 4.1.2128-2130). He is saying that a slave is absolutely equal to a king. Here we can see Shakespeare beginning to question the very idea of kingship. He implies that kingship does not really exist and that all humans are equal. This is an attempt to undermine kingship to make the prospect of a new king in England somewhat less terrifying. Shakespeare also uses his treatment of Henry to legitimize his current monarch, Elizabeth, who is a direct descendant of Henry V.

Now that we have looked at who Henry was historically, and how Shakespeare uses and alters that historical Henry in his play, let's examine the Medieval makings of a great leader. From the works of Machiavelli in The Prince and Christine de Pizan in The Body Politic, we can deduce three important traits of a successful medieval ruler. The first is the concept of "cruelty well-used," or the idea that cruelty is in fact a tool that should be utilized by a leader in order for 
him to be successful (Machiavelli 36). Machiavelli asserts that a leader "must either pamper people or destroy them" (Machiavelli 10). Pizan supports this notion of cruelty being a good trait in a leader by arguing that "the good prince ought to be feared despite being gentle and benign" (Pizan 38). The motivation behind this aspect of a good leader is that they are able to act morally ambiguous in terms of cruelty in order to ensure that their kingdom is safe in the long-run. The second aspect of a good leader is that they "love, fear, and serve God without dishonesty" (Pizan 11). This plays into the heavy emphasis on religion during the time, as well as the conceptions of divine order of the universe and the divine right of kings. The final trait leaders must have in order to be successful in the eyes of Pizan and Machiavelli is to have a deep understanding of the common people. According to Machiavelli, one has to be "a man of the people to know the character of a prince" (Machiavelli 4). We can see this play out in Henry V's journey from the tavern to the throne. The lessons Henry learns in the tavern allow him to be the great prince that he turns out to be in Henry IV Part II.

Shakespeare uses all of these element of an ideal medieval leader to set up Henry V as history's ideal king. However, throughout Henry $V$, Shakespeare works to undermine all of these qualities he has intentionally set up in Henry's character. For example, Shakespeare contradicts the idea of well-used cruelty being "short-lived and decisive" that a ruler uses "no more than is necessary to secure your position and then stop" by using it to support one of Henry's cruel actions, but he entirely ignores it as a possible explanation of the war crimes that Henry commits (Machiavelli 36). We can see how this applies to and explains Henry's Harfleur speech, but it could do the exact same for Henry's tactical reasoning behind killing the French prisoners of war. Instead, Shakespeare has Henry react emotionally to the murder of the boys in order to 
justify the action as not a war crime but an emotional response to injustice. In doing so, he undermines the idea of Henry as a good leader because he responds in a reactionary manner as opposed to the calculated cruel way that Machiavelli and Pizan assert is best for a kingdom. Shakespeare sets Henry up in that scene as a man who is motivated by revenge and not what is best for his kingdom. This undermines Henry's leadership. There is also the notion of just war that Shakespeare plays with here, which assumes "that appropriate efforts will be made by all parties involved in the conflict to protect non-combatants from harm" (Mattox 39).

Shakespeare's Henry does not do this with his Harfleur speech and as such he is going against the idea of a just war, yet Shakespeare is not utilizing the Machiavellian concept of war by avoiding the justified cruelty in Henry's war crime.

Shakespeare also undermines the idea of piety and the concept of Henry as a pious king. This is done mostly through Shakespeare's continuous acknowledgement of the fact that Henry is not authorized to rule by God until after the English victory at the Battle of Agincourt. There is an idea that "Henry can hardly be held accountable for what otherwise might seem like wartime atrocities when God Himself has authorized them" (Mattox 39). However, this authorization from God does not come until after those atrocities have been committed. The support of the corrupt church, through funds from Canterbury at the beginning of the play, does not count as divine authorization. Not only does Henry have no divine right to the English throne by being the son of the usurper, but by having no right to the English throne he has no right to the French throne either. His war is not sanctioned by God, and we can see Henry move further away from God's graces when he questions the idea of divine order. 
Finally, Shakespeare undermines the conception that he set up originally in Henry IV Part One, of Henry being a man dedicated to and part of the common people. Shakespeare argues that Henry does not understand the common people through Henry's argument with Williams and Bates the night before the Battle of Agincourt. Williams claims that it is the king who is to blame and that this blame "will be a black matter for the king" who leads his soldiers to war and "who to disobey were against all proportion of subjection" (Henry V 4.1.1991-1994). This is what Henry's men think of him and how they view his cause. It is not about honor for these common men, but about dying. Henry does not understand the common people, although he may claim to, because his justification for this war is based on justice and honor. He has been away from the tavern for too long and is caught up in royal pursuits of honor and justice. He has forgotten about the men who are not concerned with those things but with their lives and their children. Just because there is no explicit question as to "the justice of the war or Henry's right to wage it," does not mean that that question will not be in the minds of everyone watching (Mattox 38). By including the argument with Williams and Bates, Shakespeare allows the common people to have a voice and to air their grievances over the justification of kingship and war in general.

Now let's move into a discussion of the culture that Shakespeare was a part of and how that culture influenced Shakespeare. There are many elements of medieval culture that are entirely foreign to us in the modern age. For instance, "cosmic order was...one of the master-themes of Elizabethan" society (Tillyard 14). This order was created by God to provide structure to the universe in which every man, angel, animal, plant, and mineral had their place in the chain. This chain makes "references to the places of God" and "the king...in their due 
degrees" (Tillyard 15). Everything was part of this order. This order was held up and created through the use of ceremony as well as the divine right of kings. Ceremony is credited as the creator and maintainer of this order. It is this same ceremony that Shakespeare undermines through Henry. This belief in order also led to Elizabethans being "appalled by the visible tokens of disorder that suggested [order's] upsetting;" in fact, Elizabethans "were obsessed by the fear of chaos" (Tillyard 16). This Elizabethan conception of chaos is very different for our current conception of chaos. For Elizabethans, chaos "meant the cosmic anarchy before creation" which would lead "the law of nature to cease functioning" (Tillyard 16). This is what Henry is creating when he questions ceremony and divine order in his soliloquies. He is saying that the world is chaos and, not the chaos as confusion that we know, but the complete failure of the law of nature and God's structure to the universe. This is what Henry says the world is when he denounces ceremony. By denouncing ceremony, Shakespeare is discrediting everything his audience knows about the structure of the world. Their conception of war and when a country should go to war was also very different from our understanding. For instance, for an Elizabethan, war was a "part of the great cosmic scene" and was "to the body politic as the medical operation of bloodletting is to the human body" (Tillyard 7). Here we can see that the Elizabethans had a medical understanding of war. The medieval understanding of medicine influenced and was reflected in their understanding of the merits of war. This implies that war is only to be done when a country is sick or ailing. One of the most notable aspect of the Elizabethan age "was that it contained so much of the new without bursting the noble form of the old order" (Tillyard 8). We can see this element of Elizabethan culture deeply reflected in the way in which Shakespeare depicts the character of Henry. Shakespeare introduces new concepts and questions the order of the world 
without completely undermining it: while his characters question this order, they still live within it. We can see here how Shakespeare is using Henry to introduce new concepts to his culture and how Shakespeare is trying to manipulate his society and their political views while still operating within the realm of those views. He pushes the order without completely destroying it.

While not entirely dismantling the system of divine order, through his interpretation of the story of Henry V, Shakespeare does work subversively against that order. To understand how this subversion worked and was utilized by Shakespeare, we must first understand that Shakespeare's plays were "the playings-out of particular actions imagined by an author who is himself being played upon by--and adjusting to--the circumstances of his imagining" (Altman 2). Shakespeare is directly influenced by his surrounding and culture. He did not write in a vacuum and as such we can see the playings out of his various fears and concerns of the time throughout his play as he is playing-out the stress of succession. Thus, we must be very careful not to "aestheticize the play or...anaesthetize and immobilize it" by removing it from its culture and its context (Altman 2). This play needs to be viewed as a piece that was a participatory element of its culture. This is the nature of theatre and to remove theatre from its audience and its context veils its meaning. The meaning of this piece is illuminated when one understands the complexities of the political succession, Elizabethan worldview, and medieval leadership ideals that had a huge effect on the cultural understanding of that time. By acknowledging the cultural and political backdrop of this play, we can see how Shakespeare specifically uses the platform of theatre in order to question and subvert that backdrop. For example, as this play is played out "on the stage, a fifteenth-century past is urged into presence by contemporary players" while contemporary audiences "piece out its imperfections by prescencing it in their imaginations" 
(Altman 16). The mere fact that this is being performed by the audience's contemporaries makes it subject to the contemporary political system, stresses, and culture of its time. Henry's "greatness depends on mutual participation," and without the context of its audience and the culture that audience operated within the play is useless (Altman 20). In addition, there was no way for a writer to "free [a character] from the context of sin and its atonement" that was so overwhelmingly present during the Elizabethan period (Tillyard 20). We see this in Shakespeare's presentation of Henry V when Henry atones not only for his own sins but the sins of his father who disrupted the order of the universe after he dismantles the idea of divine order. Even while trying to question this order Shakespeare was forced to operate within it and to apologize for it through Henry's own repentance.

Along with cultural ideals, the political events that occurred during the time of this play's conception were fundamental in shaping how Shakespeare decided to portray the character of Henry on stage. The most pressing political issue during this time was Elizabeth's aging and, as a result, her declining health. As a woman with no heirs, it was uncertain as to who would hold the throne of England after Elizabeth's death. This play “is a succession play, a work grounded in the anxieties of a country whose queen...had no acknowledged successor," and feeding into these anxieties was the fact that "various parties--Spain openly and immediately, Scotland more circumspectly--were prepared to use force to impose their own candidates" for the English throne (Dutton 184). This issue of a Scottish succession to the English throne is what drove most of Shakespeare's characterization of Henry V in his play Henry V. Shakespeare's stress and concern over this succession can be seen creeping into the play through the ambiguity of Henry's character. As Dutton states, "the succession issue was always integral to the play's conception" 
and always will be (Dutton 185). From the quarto to the folio and beyond, the very nature of the play makes it a succession play. The major themes of this play are succession and the right to the throne. To ignore these themes is to take the play out of the political context that not only surrounded it but created it.

Shakespeare structured his play Henry $V$ in response to his and his society's fears of succession. For instance, the play focuses not on the battle of Agincourt "which is textually almost a non-event" but instead focuses on the emotional life and fears of Henry and his men the night before the battle (Dutton 192). The reasoning for this is because it "mirrors the actual threats to [England] in 1599" and the fears that at any moment Elizabeth may die and "cast England into a civil war over the succession" (Dutton 192). Essentially, "England was praying for an agincourt-style miracle" as they dealt with the threats posed by this succession question (Dutton 192). This play does not deal with war but the night before. The sense of fear and hopelessness represented by the night before the Battle of Agincourt reflects what the English were feeling before the succession of King James to the English throne. Shakespeare used his source material to show England in one of its darkest moments before one of its greatest victories. This could have been Shakespeare's attempt to give his audience a sense of hope that they may be able to make it through this battle for the English throne just as Henry and his men made it through the Battle of Agincourt. This sense of foreboding and fear of the night before a battle can also be found in the ambiguity that Shakespeare creates and uses throughout the play. Henry $V$ does not make any firm claims but hangs in the balance. It is a waiting play gripped in the liminal space between two rulers. In addition to focusing his play on the night before the battle, Shakespeare also writes his play to "question the insidious logic of hereditary privilege" 
and exposes "it to be nothing other than an abuse of history" (Hall 28). We can see this questioning in the very nature of Henry's character not having Divine Right or hereditary claim to either the throne of England or of France, yet he is still the most glorified king that Shakespeare writes about in any of his history plays. He is England's most beloved historical figure yet he had no right to be on the English throne in the first place. In crafting Henry's character in such a way, Shakespeare questions the entire concept of kingship and the history of government in England because he argues that the concept it is based on, hereditary privilege, does not affect the quality of a leader.

Complications arise in Henry's character as he notably mirrors the biggest threat to English succession: King James of Scotland. The first and most striking similarity between these two kings is the paralleling that Shakespeare uses in their right to succession and their reasoning for seeking the throne of another country. In Henry $V$, Shakespeare "capitalizes on the notion that the throne of France has been wrongly withheld from Henry" (Mattox 31). When looking to James, we can see that "James's claim to England was at least as strong as that of Henry to France" (Dutton 186). This creates and enforces the ambiguity of Henry as he both mimics and is threatened by James. Here we can see that these two characters mirror each other. This may be why Henry is such an ambiguous character, because Shakespeare is not yet sure how he should approach the idea of James as his possible kingship looms in the distance. We should also take into account that, for Shakespeare's audience, Henry technically didn't have a right to the throne of England. Without being able to justify one's right to the throne these two would-be kings become nothing more than "renegade leader[s] bent on wreaking havoc among the community of civilized nations" (Mattox 33). Throughout the play we are continually reminded that Henry is 
the son of a usurper. We can also see Shakespeare criticize James's claim to England through Henry's actions when we examine the idea of proportionality in relation Henry taking over the crown of France. Specifically, Shakespeare "offers no argument in the play in behalf of proportionality" for Henry claiming right to the crown of France which "suggests that [Shakespeare]...recognizes that a plausible defense of Henry on this matter would be difficult to come by and...elects to sidestep the issue altogether" (Mattox 37). This is very important because in not dealing with the issue, Shakespeare leaves it incredibly ambiguous and this ambiguity will make intensive claims in terms of James's right to the crown of England. Shakespeare does not give a justification to the proportionality of Henry taking over France because this may give justification for James taking over England. There is a level of ambiguity here because Shakespeare needs to tread carefully due to the threat of succession. If James is crowned king it is favorably that Shakespeare's play be taken as a pro-Scottish play. Essentially, the similarities between James and Henry highlight the English terror of succession by a foreign invader, as "Scotland had always been an unsafe back door" through which English national security could be threatened and undermined (Dutton 187). There is a possibility for foreign invasion and take-over because of the succession issue. These are very real fears. Henry is what the English fear because he is so similar to James in terms of his justification of taking the French crown. Henry becomes the ambiguous boogeyman that represents everything the English fear from James. In making this beloved English king the embodiment of his audience's Scottish fear, Shakespeare allows his audience to confront their issues with succession head on.

Through his discussion of Scotland, Shakespeare begins to question the idea of Scottish nationhood as a whole. The erasure of Scottish nationhood can be seen most clearly with 
Shakespeare's creation and depiction of the Scottish Captain Jamy. Captain Jamy is described by Fluellen as a "marvelous, valorous gentleman" (Henry 3.2.1195-1196). It is no coincidence that the only Scottish character present in Henry $V$ has a name so similar to the of the Scottish king. This can be viewed as an attempt to cast James as part of the English army; therefore, as a part of the English sense of nationalism and the English nation as a whole. In fact, Captain Jamy may be a way for Shakespeare to assert that "Scotland itself moves, and should always have moved (but for its straying), within England's jurisdiction" (Hutson 18). Thus, King James is not actually Scottish but is and always had been English and part of the English nationalism that encapsulates all of the British Isle. Shakespeare also makes the argument that Scotland has and always will be on England's side by having the character of Captain Jamy being kindly characterized by Captain Fluellen. There is something reassuring in the fact that King James is not separate from the will of the English people but a part of the English themselves. By becoming part of "Henry's proto-British army" King James is robbed of his nationhood as a Scottish king and taken into the fold of English nationalism (Warren 12). Here we can see an attempt on Shakespeare's part to force Scotland to assimilate into English nationalism. This is also an attempt to ease the fear of a Scottish ruler because he would not be foreign but an English man returning to his rightful throne.

In general, Shakespeare's Henry has a very complex relationship with the King of Scotland as well as the idea of Scottish nationalism as a whole. For example, after agreeing to go to war with France Henry discusses his concerns of "the Scot, who will make road upon [England] with all advantages" once he and his army have left England to pursue the crown of France (Henry V 1.2.283-286). Here we see the ambiguity of Henry's relationship with Scotland. 
Not only does this contradict the sense of Scottish citizens being part of the larger fold of English nationalism, but it also has Henry, who mirrors the Scottish King James, arm himself against the Scottish people. This produces a dichotomy in the way in which Shakespeare presents the idea not only of Scottish nationhood but the Scottish people as a whole. There's a huge theme of otherness in this play with both Henry and James being foreign kings. This discussion of otherness and Shakespeare's complicated relationship with Scotland stem from the fear that someone who is not English will end up being on the English throne. Shakespeare's own fears about losing his culture and sense of English nationalism are reflected in the way in which he undermines Scottish nationalism. In doing this, Shakespeare is able to neutralize the threat of a Scottish succession to the English throne.

Shakespeare continues to grapple with the issue of Scottish succession through his personalization of English nationalism as a whole. By packaging these huge themes of succession, hereditary right, and kingship into the likeable and relatable character of Henry V, Shakespeare begins to make "the English national interest seem supra-nationally inclusive" because he identifies this nationalism "through the mystery of Henry's unknowable individuality" and as a result of this he subtly denies "the existence of other national causes," most importantly those national causes related to Scotland and Scottish nationalism (Hutson 4). By making the issues of kingship and divine right personal instead of ideological, Shakespeare invites his audience to grapple with these themes and how they interact with the audience's daily life. He gives his audience access to these concepts that their government is built on and invites them to question these ideas in relation to their topical concerns about succession. In doing so, he creates a discussion with his audience that was typically reserved for the elite who benefitted 
from these principles. This discussion among the common people would work subversively against this government and the pillars that supported the English political system. In addition, by creating this overarching sense of English nationalism, Shakespeare brings Scotland further into the fold of Englishness. Through that Englishness, Shakespeare is "very effectively and cleverly denying Scotland the historical status of a nation, just at a point when that historical status mattered a great deal" (Hutson 7). Shakespeare pushes away the idea of Scottish succession through his denial of Scottish nationhood and his inclusion of Scotland in the idea of Englishness. Essentially, Scotland becomes the wayward child of England as opposed to its own nation. In one sense this is incredibly disturbing as it erases the entirety of Scottish culture, but, on the other hand, it eases the stress of succession by asserting that if King James were to be crowned King of England, it would an Englishman assuming his rightful position as king. Through his depiction of the idea of succession and Scotland, Shakespeare seems to be trying to characterize King James's rise to the throne of England "not as the conquest of a foreign nation but as the recovery of the king's inheritance, not as a confrontation with the other but as reunion with part of oneself." (Patterson 132). Yet, present still is a strange dichotomy in the way in which Shakespeare represents Scotland and Scotland's King James. Through this dichotomy we can see the ambiguous nature of Scottish succession in Shakespeare's play. This is one of the many ambiguities that Shakespeare will use to not only subvert Elizabethan politics but to protect himself in the case of a Scottish succession.

Now that we have uncovered the ambiguous elements of Shakespeare's Henry V, let's look at the three ways in which Shakespeare uses these ambiguities to his advantage. The first way in which Shakespeare utilizes ambiguity in Henry $V$ is to deliver a subversive message 
about the culture and values of his time. For instance, Shakespeare understood that "language is a culturally and socially saturated tool" and "that linguistic performances are never neutral" and as a result of this they are "a weapon to express diversity, dissension, and conflicts of interests;" therefore, Shakespeare sought to "exploit or even strive to enhance that potential" that was already present in his presentation of these ideas through his history plays (Pugliatti 238-239). Shakespeare intentionally created the conflicting elements of his text that make up these ambiguities for the benefit of his audience. The conflict he created is both built from the conflicts already present in his political, social, and cultural system as well as a commentary on those conflicts. He creates this conflict by playing on cultural understandings of the universe, interpretations of good leadership, and the cultural glorification of Henry V. The conflict between what the audience knows and what they see onstage results in the ambiguities that will serve as a commentary on his current political system. In fact, through his play, Shakespeare creates an "ambivalent representation of both Henry V and his war" which lives in direct contrast "with the great nationalist fervor that is presumed to have attended the play's early performances" (Altman 8). The ambiguity is a result of the conflict Shakespeare creates between what his audience expects to see and what they actually see in his production of Henry $V$. Shakespeare uses this ambiguity to challenge his audience's preconceptions about kingship and the divine order of the universe. His history plays themselves are intended to "expose the way that a fictionalized past is used to justify what is instrumentally expedient in the present;" a past history that "is ripe for exploitation in the present" (Hall 27). Through Henry V, Shakespeare is able to comment on his own political system and how that political system relies on idealized instances from the past to justify its current structure. In creating this commentary, Shakespeare 
manipulates history in a similar way, but instead of trying to justify the political status quo through these manipulations, Shakespeare question it. Shakespeare wants his audience to view his play through the lense of the present and "deliberately jolts his audience into seeing the present in his recreated past by putting in contemporary details they could themselves have experienced"(Moseley 95). In order to intentionally bring the play into the present, Shakespeare specifically uses colloquial terms. This forces his audience to view his play through the topical political concerns of their time. This shows us that the questions Shakespeare raises about succession, hereditary right, and kingship are all deliberately targeted at issues he and his contemporaries are dealing with at the time that the play was written and performed. In the end, the play is "unable to decide between an optimistic and a pessimistic model" for the way in which it presents this history, and it ends up leaving us with the sense that "all (the play's all as well as history's all) was for nothing" (Pugliatti 253). The dualism and ambiguity in the way the play portrays Henry V reveals a lot about what Shakespeare feels in relation to the succession stress he is dealing with. It creates a level of ambiguity and confusion over how Shakespeare wants his audience to feel about Henry by the end of the play. It implies that no matter how good the king acts or no matter how wonderful the performance, in the end it doesn't matter. In a roundabout way this cynicism works to ease fears of the succession because in the end, regardless of what happens, it will not make that much of a difference.The second reason for the ambiguity present in Henry $V$ is that it is an effective way for Shakespeare to protect himself and his work from censorship. If King James comes into power, it is important that Shakespeare's play is not seen as anti-Scottish. It is essential that regardless of the outcome of the succession, Henry $V$ be praiseworthy to whomever becomes the new leader of England. The most effective 
way for him to do this is ro make all of his claims about Scotland and England ambiguous. Shakespeare covers his tracks through ambiguity in a number of ways. The first is by staying as close to his source as possible and only veering from it when it is not explicitly dangerous to do so. For the most part, "Shakespeare would be careful to cover his tracks" sticking as close to his source text, "in an age notorious for paralleling" (Altman 21-22). We can see that Shakespeare remains very close to his source in Holinshed: his only deviations are disguised by his use of cultural narrative surrounding the historical figure of Henry V himself. Shakespeare is covering his tracks in order to make sure that these radical claims about kingship and divine order do not get him killed. Shakespeare also used "the habit of historical paralleling" as "part of the stage action," and in doing so is able to cast Henry "in a satisfyingly ambiguous light" while still taking the appropriate "measure against the time's constraints" (Altman 24). This shows how Shakespeare was operating within the confines of his time, and he worked through those restrictions in order to question and undermine the conceptions of kingship and divine order. By working within the constraints of his time, Shakespeare protected himself from censorship while still making subversive claims about his culture. In addition, these continual debates over the political ambiguities present in the motivations of Henry V demonstrate how "the play...will not speak mono-vocally as either apology or critique" (Warren 9). Shakespeare is intentionally speaking with two voices in order to assure he is alive after the succession happens. By being duplicitous in the voices he uses through the ambiguities present in Henry V, Shakespeare is able to negotiate the changing tides of English politics. In fact these ambiguities present in the play paint Shakespeare as "one concerned with drawing audiences into the plays' topical concerns--obliquely, allusively, non-confrontationally" (Dutton 175). By approaching these 
topics in a way that was not confrontational to his audience or those in power, Shakespeare was able to make claims about society and kingship while still ensuring his survival after James took the throne. Shakespeare knew how to subvert a political system while still working within the confines of that monarchy which refused to be undermined. He learned to hide his free speech in plays that were meant to praise the very rulers he was undermining. We can therefore view "Shakespeare as...a time-server...who, unable to transcend his time, perceived its liberties and its restraints...and played out their possibilities on his stage" (Altman 32). Again, we can see that this ambiguity existed because it showed the problems of the time in a digestible way, which protected Shakespeare and allowed him to express his own views about the conception of succession.

The final way in which Shakespeare employed this ambiguity is by using it to express his own fears and stress surrounding the issue of political succession. For instance, it can be assumed that the predominant intent of Henry $V$ was that of glorifying the king and the battle but "a deeper deglorifying conviction" ended up emerging through the ambiguities that Shakespeare explicitly put into his play (Pugliatti 236). Shakespeare intentionally created this sense of ambiguity in regards to how Henry was presented because he was trying to manipulate his audience and give them a way to understand the succession crisis that was happening in 1599 . He was also allowing some of his own fears and concerns seep into this examination of leadership and succession. His own concerns over what a leader should be become evident in the ambiguities of Henry V, as he writes him. This "play may be considered one of the definitely ambiguous or ambivalent works of world literature" and this heavily present ambiguity is illustrative of Shakespeare's own concerns and confusion surrounding the questions he is asking 
(Pugliatti 235). This play may ask many challenging and alarming questions about leadership, kingship, and divine order, but it does not offer any explicit answers to any of these questions. The nature of Henry $V$ is highly speculative due to the ambiguities Shakespeare creates. By using this intentional ambiguity, "Shakespeare is trying to present a polymorphous or polyphonic political picture," one that will raise questions and concerns over the political climate of his time (Pugliatti 237). By creating this multifaceted political nature in the play, Shakespeare highlights the feeling of political uncertainty that was overwhelmingly present in Elizabethan culture in 1599. During the time when this play was being written and performed England "lurched from one short-term crisis to another, and the fear of rebellion or subversion from outside was" accompanied by the equally stressing fear of "vicious civil war" (Moseley 93). Here we can see the social unrest and political uncertainty that was prominent in the cultural context of this play. Shakespeare was driven to write this piece because he was trying to deal with the cultural fear that was sweeping his nation. This fear and uncertainty resulted in the development of so many ambiguities throughout the play.

All of these ambiguities are brought into the forefront by the way in which Shakespeare utilizes the character of the Chorus. The presence of the Chorus in Henry $V$ is effectively used as a way to "illustrate the virtues of the ideal king, anticipate the content of the following act, and fill up the gaps by telling the events that are not going to be represented;" however, the Chorus's function "is not only metadramatic, since many evaluations are suggested...by them" (Pugliatti 251). This shows how the Chorus takes an active role not only in guiding the audience but in suggesting how the audience should evaluate the king they see on stage. The Chorus even goes so far as to make explicit claims about the character and quality of the king. These evaluations 
are important because they come from the Chorus who is "nearer--temporally, but also socially--to the audience than most of the perspectives that are to be found in this play," and, as being thus, the Chorus is "nearer, and therefore, trustworthy (psychologically, if not historically)" to the audience (Pugliatti 251). It is significant that, as the most trustworthy character in the piece, the Chorus sets Henry up as a shining example of kingship. This characterization of Henry by the Chorus becomes even more important when we realize that this occurs during and throughout a play in which we see Henry commit acts that are questionable at best. The Chorus's use of a celebrative tone is at odds with the way in which Shakespeare presents Henry throughout the play. In fact, if one were to only read the Chorus's speeches, "none of the doubts...about the celebrative intention of the play would arise" (Pugliatti 251). But Shakespeare put the Chorus's celebration of the king with the rest of the play intentionally. It is a part of the play and as being part of the play we can see that the questions and ambiguities brought up by this inclusion were intended to be there by Shakespeare. Indeed, Shakespeare does not use the Chorus to this magnitude in any of his other plays and as such examining the Chorus as a character "will help us to recognize the signals Shakespeare is giving his audience, and thus the parameters of the construction of the play" (Moseley 116). The Chorus works as a way for the audience to see the ambiguities, and with them questions, that Shakespeare builds into his Henry $V$. There is "an important darkness at [Henry V's] heart" that serves as the backdrop against which "the portrait of Henry himself is acted out" (Dutton 201). This darkness is brought to light by the Chorus's glowing endorsement of Henry. We get to see these ambiguities because of the contrast that the inclusion of such a positive Chorus creates with the rest of the piece. As a way to apply these ambiguities to topical concerns, the Chorus claims that Henry is "the mirror 
of all Christian kings" (Henry V 2.1.468). As the mirror for all Christian kings, the claims that Shakespeare is makes about kingship are meant to be universal and applicable to any and all Christian kings. The Chorus is the one to emphasize the universality of Henry's claims about kingship.

These universal claims about kingship, made by Shakespeare in this piece, seek to undermine the notion of a monarchy altogether. When we look at "the judgement that the play seems to pass on the most celebrated and heroic of the English kings" and the ambiguities and questions Shakespeare raises in passing this judgement, we can begin to discern the larger arc of "Shakespeare's political attitude" (Pugliatti 235). Shakespeare is making a political statement about the role of kings and kingship in his society. He's trying to undermine conception of a monarchy as that political system is in flux due to its own failings. It is also important to note that in his presentation of Henry in Henry $V$, "the old subversive comedy" of the tavern "does not even touch the King" (Pugliatti 248). Removing that comedy also makes Henry a very different kind of character than he is in previous plays. It allows the audience to witness the weight of the crown, and watch a man who was not born a prince become king. The removal of Henry from his group of clowns sets him up as an other, as someone alone, and isolates him from the man he was, because now he is forced to be something devine. The subversiveness comes in with his questioning of that kingship that robbed him of his friends. Here we see the idea of kingship as an institution which separates man from his fellow man. Once these ideas are combined with the questions Henry poses about divine order, ceremony, and hereditary right, we can see that Shakespeare "demystifies royal authority" through his portrayal of Henry (Warren 7). By demystifying kingship he makes the prospect of a bad king less concerning because that 
king is only a man; therefore, he is subject to the same failings as any other man. He seems to argue throughout Henry $V$ that kingship is not a divine intervention into the lives of humans but a political construction. Shakespeare emphasizes the construction of a king through the fact that "in image and in practice Henry's kingship defined itself in terms of the contemporary language of public virtue"(Patterson 131). Shakespeare shows us how he constructs King Henry as England personified by using public virtues, medieval political ideals, and Elizabethan culture to manufacture the perfect English king. He continually points out this construction through his repeated ambiguities surrounding the justification of Henry's right to the title of King. Shakespeare's final attack on the concept of kingship is his denouncement of the idea of hereditary right and inheritance which are "the basis of medieval and Elizabethan society" and its political system (Moseley 100). Shakespeare questions all of that by having his best king have no real right to either of his thrones. This shows us that inheritance and the conception of succession are not as important or real as his society believes.

These discussions of ambiguity, leadership, and kingship ask important questions of the political systems of Shakespeare's time and our own. The largest implication of these questions stems from the heavy emphasis on theatricality throughout the play. There is debate over why "Shakespeare should have resorted to such an unusual dramatic form in the first place" (Altman 1). In making this play so theatrical, Shakespeare implies that leadership is a performance which in turn suggests that it is a teachable skill, one which anyone (as shown through his actors) can perform well. In addition, "it is through the barefaced lies of drama" that Shakespeare is able to expose "the politic mendacity, jingoism, and selective amnesia inherent in the accounts of history from which Shakespeare drew" (Hall 22). By making the plays theatrical, Shakespeare 
questions not only how a government should operate but how we remember our leaders. If the claims that Shakespeare's Henry makes about kings being the same as any other man are true, then we should remember all kings are men, as opposed to glorified ideals. Shakespeare shows his audience that in order to learn from and find comfort in our past we must present it in all its ambiguity as opposed to simplifying it into a patriotic cultural narrative.

This play deals explicitly with the stresses and consternations accompanying the changes of leadership in a government. Through Henry $V$, Shakespeare expertly navigates the dangers of political dissent. By examining this play in the modern era we can begin to deal with our own stresses concerning succession and leadership. The implications that this play makes about leadership being a type of performance suggests that it is a teachable skill. As such, one could conclude that no one is born a good leader but that good leaders can be made. This idea that leaders are constructed and not born has interesting implications in the current political environment in the United States of America. The current President of the United States, Donald Trump, will one day have a successor. Whether he is impeached or loses the re-election, there will be another President after Donald Trump. The quality of this successor is still unknown. Regardless of the quality of this successor, as we move forward as a nation we need to examine how we are constructing our leaders. We need to raise questions and deal with the stresses of our own looming political succession. I would argue that we could do so in the same way that Shakespeare did: through theatre and theatrical performance. 